\title{
The Influence of YouTube as a Classical Guidance Media on Student Learning Motivation during the Covid-19 Pandemic
}

\author{
Khuzaimatul Jannah ${ }^{1^{*}}$, Babay Baqiyatussolihat ${ }^{2}$, Reni Vernandes ${ }^{3}$ \\ ${ }^{1,3}$ SMP Negeri 3 Kragilan, Kabupaten Serang, ${ }^{2}$ SMK Negeri 1 Ciruas, Kabupaten Serang \\ *Corresponding author, e-mail: khuzaimatul66@gmail.com
}

Received August 02, 2021; Revised August 31, 2021; Accepted Sept. 20, 2021; Published Online 2021-10-01

\section{Conflict of Interest} Disclosures:

The authors declare that they have no significant competing financial, professional or personal interests that might have influenced the performance or presentation of the work described in this manuscript.

\begin{abstract}
This study aims to determine the influence of YouTube as a classical guidance media on learning motivation in students during the COVID-19 pandemic. This experimental research uses Posttest Only Control Group Design. The research population is students of $1^{\text {st }}$ grade SMP 3 Kragilan. The research sample consisted of 40 students through random sampling technique, 20 students were the experimental group and 20 students were the control group. Data collection in this study used a questionnaire. The data in this study were analyzed by independent samples t-test using SPSS 16.0 for Windows. The results of the study obtained t count of 2,329, found t table at a significance level of pada (0.05) of 2,021, which means $t$ table $<t$ count. These results prove that YouTube as a classical guidance media has an influence on student learning motivation during the COVID-19 pandemic. Classical guidance media used youtube has several advantages over other classical guidance service media, by using youtube as a learning media, students are more interested and enthusiastic in participating in classical guidance services. The author suggests the application of YouTube as classical guidance media that can influence students' learning motivation.
\end{abstract}

Keywords: Youtube, Classical Guidance, Learning Motivation.

\section{Introduction}

Since Covid-19 hit Indonesia, the government has encouraged all people to carry out activities from home. The purpose of the policy is to reduce the spread of COVID-19 in Indonesia. The policy also certainly has an impact on all aspects in Indonesia, include teaching and learning activities. The government then recommended that all teaching and learning activities be carried out online which known as Learning From Home or online by utilizing existing technology. Basilalia \& Kvavadze (2020) define online learning as a knowledge transfer experience using video, audio, images, text communication, software. Online learning allows teachers and students to continue to carry out learning even though it is carried out far apart. This online learning is not only effective in reducing the spread of COVID-19 in Indonesia, it is also effective in 
transferring knowledge through various platforms that can be accessed by teachers and students. According to Sadikin \& Hamidah (2020) online distance learning is effective for overcoming learning that allows teachers and students to interact in virtual classrooms that can be accessed anywhere and anytime.

Learning activities from home also affect the learning methods that have been carried out directly or face to face. Online learning or learning from home requires teachers and students as well as all elements of the school to be more familier using and utilizing technology. Bao (2020) reveals that teachers and educators as an important element in teaching are required to make an unprecedented large-scale migration from traditional education which learning by face-to-face to online education. it also makes teachers and other educators have to be good at exploring technology and developing it into new innovations that are refreshing and effective to use in online learning. All school stakeholders try to adapt learning method according to this current conditions and tried to maximaizing learning and guidance for students. Beside preparing mental readiness to face online learning, we also need to prepare other supporting infrastructure to support the success of online learning. Abidah, Hidaayatullaah, Simamora, Fehabutar, \& Mutaqinati (2020) revealed an infrastructure that can support online learning for free through various discussion rooms such as Google Classroom, Whatsapp, Smart Class, Zenius, Quipper and Microsoft.

The massive migration carried out in order to implement online learning in the midst of this pandemic is not only carried out by subject teachers in the teaching and learning process, but also by guidance and counseling teachers in providing services. Isti'adah, et al (2020) reveal that guidance and counseling as part of education has sued to making adjustments to these advances, adjustments in giving service must be done in a different way form usual. One of the services that can be implemented during this online learning is the classical guidance service. The Ministry of Education and Culture (2016) defines classical guidance as a service provided to students in a class/study group led by a BK teacher or counselor with the aim of helping students achieve independence, complete development, and harmony between thoughts, feelings, and behavior. in demand. Classical guidance can be carried out online by utilizing available platforms such as Zoom, Google Meet, Whatsapp and so on.

Dwi, Amelia, Hasanah, Putra, \& Rahman (2020) said that not all activity of providing online-based material was effective. Online learning that carried out at home makes students' motivation on learning is less than usual. Syachtiyani \& Trisnawati (2021) revealed that learning motivation is closely related to individual achievement. Learning motivation also known as an encouragement that arises both from within and from outside students to behave in achieving learning success. Research that conducted by Cahyani, Listiana, \& Larasati (2020) shows that the learning motivation of students who take part in online or online learning in the midst of the COVID-19 virus pandemic situation has decreased. The descriptive data of the study showed by 344 students, $52.6 \%$ of them admitted that their enthusiasm for learning decreased during online learning. This research was strengthened by Syachtiyani \& Trisnawati (2021) who said that the results of observations showed that students were happier to do learning at school because it could motivate or encourage students' enthusiasm for learning to compete in a healthy manner with friends.

Beside of using the right platform, the success of classical guidance online services also depends on the media that used in carrying out classical guidance. One of the learning media that easily accessible and owned by all students is YouTube. Mujianto (2019) said that the use of YouTube as a learning media played a significant positive role in increasing students' interest and motivation in learning. Counseling guidance teachers can create content or videos according to the theme of the counseling guidance service that will be carried out according to what studensts' need. Beside of creating their own content, guidance and counseling teachers can also use oher content creators videos, because there are many content creators who discuss selfdevelopment, social life, good ways of learning and even how to choose a career that matches your interests and talents.

Counseling guidance teachers can use youtube media to carry out counseling guidance services to develop student potential. One of the counseling guidance services is the classical service. According to POP GTK BK (2016) "classical service is a service activity provided to a number of students in a class unit or a study group (rombel) and is carried out regularly in the form of face-to-face between guidance and counseling teachers or counselors with students. / counselee".

In Kummalasari's research (2017) it was concluded that the service of the learning process in aspects of intracurricular programs (regular learning academic processes), co-curricular (consultation services for counseling guidance), and extracurricular activities (leadership development, independence, and character 
strengthening) significantly affected the level of student satisfaction. . Hutabarat (2020) concludes that the selection of learning platforms that have attractive indicators, simplicity of use, easy to understand and suitable use and the role of the teacher when online learning held is affect the level of student satisfaction in learning. So it is hoped that with the classical service using youtube media, the counselee can participate in counseling guidance activities with pleasure and satisfaction and the goals of classical guidance services can be achieved.

Based on the background and description above, it is necessary to use technology with youtube media that can help guidance and counseling teachers to carry out classical guidance services during the covid-19 pandemic. The purpose of this study was to determine the influence of youtube as a classical guidance media on students' learning motivation during the COVID-19 pandemic, the authors conducted a research entitled "The Influence of Youtube as a Classical Guidance Media on Student Learning Motivation during the Covid19 Pandemic".

\section{Method}

\section{Research Design}

This research is True Experimental Design research because the researchers used control variables and the samples that used for the experiment and the control group were selected randomly. The form of this True experimental design used a posttest only control group design so that the results of the study will show a comparison of the learning motivation of groups of students who used YouTube as a learning media, with students who do not used YouTube as a learning media.

Table 1. Posttest Only Control Group Design Research

\begin{tabular}{ccc}
\hline $\mathrm{R}$ & $\mathrm{X}$ & $\mathrm{O} 1$ \\
$\mathrm{R}$ & - & $\mathrm{O} 2$ \\
\hline
\end{tabular}

Sumber: Sugiyono (2017)

The population in this study were students of class VII of SMP Negeri 3 Kragilan, which totaling 361 students. The sampling in this research using probability sampling technique, which is a random sampling technique, without holding a pretest. The research sample was 40 students, which 20 students were the experimental group and 20 students were the control group. The use of this design can control the occurrence of testing bias and interaction testing (Dantes, 2014:78).

The measurements were carried out using a learning motivation questionnaire developed from the theory of Interaction and Teaching and Learning Motivation developed by Sardiman (2020). The learning motivation questionnaire consists of eight indicators: (1) Diligent in facing the task; (2) Resilience in facing difficulties; (3) Show interest in various problems; (4) Prefer to work independently; (5) Get bored quickly on routine tasks; (6) Can defend his opinion; (7) Inot easy to let go of what is believed; and (8) Enjoy finding and solving problems. After the classical guidance service was carried out using YouTube as a learning media for the experimental group, then measurements were made using a learning motivation scale to find out whether there was a difference in learning motivation scores between the experimental group using YouTube as a classical guidance media and the control group not using YouTube as a classical guidance media. .

The first step of this research is to determine the sample which will be divided into experimental group and control group. The experimental group will be given treatment, namely is classical services using youtube, while the control group will be given classical services as usual, namely reading and filling out Student Worksheets and Self Development (Counseling Guidance and Budi Pekerti). Implementation of classical services using youtube media is held for 4 times for 1 month, specifically in April. The influence of student learning motivation will be seen through the results of questionnaire data analysis using the Independent Sample T-test.

The analysis was carried out quantitatively using parametric statistical analysis techniques with the Independent Sample T-test analysis. The steps of analysis in this research are: 1). Prerequisites for Analysis Test, Normality Test for Data Distribution and Homogeneity Test for Variants, and 2). Hypothesis testing. The analytical technique used for hypothesis testing in this research is the Independent Sample T-test analysis technique using SPSS 16.0 For Windows.

(The Influence of YouTube as a Classical Guidance Media on Student Learning Motivation during the Covid-19 Pandemic) 


\section{Results and Discussion}

The effect of youtube as a classical guidance media in the results of the learning motivation questionnaire were analyzed using the Independent Sample T-test. The test is carried out with the following procedures: 1). Prerequisite test consisting of normality test and data homogeneity test with the results in table 2 . and table 3. below:

Table 2. Normality Test Results

\begin{tabular}{|c|c|c|c|c|c|c|}
\hline \multicolumn{7}{|c|}{ Tests of Normality } \\
\hline & \multicolumn{3}{|c|}{ Kolmogorov-Smirnov ${ }^{a}$} & \multicolumn{2}{|c|}{ Shapiro-Wilk } & \multirow[b]{2}{*}{ Sig. } \\
\hline & Statistic & df & Sig. & Statistic & df & \\
\hline $\begin{array}{l}\text { experimental group's } \\
\text { learning motivation }\end{array}$ & .107 & 20 & $.200^{*}$ & .964 & 20 & .622 \\
\hline $\begin{array}{l}\text { control group's learning } \\
\text { motivation }\end{array}$ & .146 & 20 & $.200^{*}$ & .942 & 20 & .256 \\
\hline
\end{tabular}

Based on the test of normality above, it is known that the value of Sig. of Shapiro-Wilk for the experimental group's learning motivation of 0.622 and the value of Sig. of Shapiro-Wilk for the control group's learning motivation of 0.256 . Because the value of Sig. of Shapiro-Wilk for both groups $>0.05$, it can be concluded that the learning motivation data for the experimental group and the control group were normally distributed.

Table 3. Homogeneity of Variances Results

\begin{tabular}{lccc}
\hline \multicolumn{4}{c}{ Test of Homogeneity of Variances } \\
\multicolumn{4}{c}{ Learning Motivation } \\
\hline Levene Statistic & df1 & df2 & Sig. \\
.027 & 1 & 38 & .870 \\
\hline
\end{tabular}

Based on the output above, it is known that the value of Sig. Lavene's Tesy for Equality of Variance for the variable of learning motivation is 0.870 . Because the value of Sig. $0.870>0.05$, it can be concluded that the variance of learning motivation data in the experimental class and control class is homogeneous.

Next, 2). Hypothesis testing. The results of data analysis using the Independent Sample T-test to determine the effect of classical guidance media in the form of youtube on students' learning motivation obtained the following results:

Tabel 4. Independent Samples Test Result

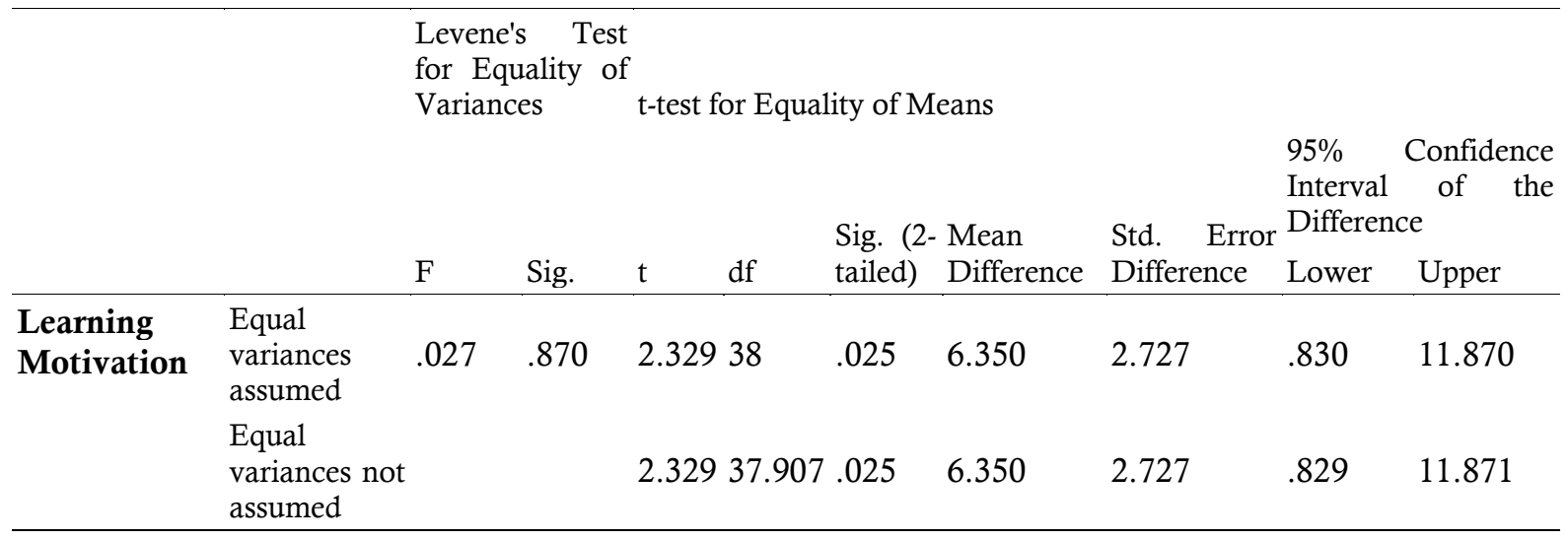


Table 4. shows that the value of $t$ count is 2.329 , found $t$ table at a significance level of taraf (0.05) of 2.021 , which means $t$ table $<\mathrm{t}$ count. These results prove that YouTube as a classical guidance media has an effect on student learning motivation during the covid-19 pandemic.

The used of YouTube as a classical service media aims to make students interested and following online classical guidance services. With the existence of online classical guidance services, Guidance Counseling teachers can motivate students to take part in online learning so that they are more enthusiastic even though they are studying from home. Guidance Counseling teachers must be creative in providing classical services so that students are enthusiastic about participating in classical services and motivation can be conveyed well to students.

The results of this research is reinforced by several previous studies that have been carried out including research conducted by Tohari et al (2019) which found that "Learning motivation of Semester IV students of the PNM Accounting Computerization Study Program who uses Youtube as a learning resource by utilization in the Database Design course for SQL material is in the very good category. There is a significant influence between student learning motivation using Youtube as a learning resource by utilization in the Database Design course for SQL material on student learning outcomes". With the help of Youtube media as a learning resource, student learning motivation is in the very good category so that it produces good learning outcomes as well.

The results of Farhatunnisya's research (2020) note that the use of the youtube application media in increasing the motivation of Insan Litera students needs a part to help guide and direct them so that they are able to be motivated to learn. Through educational films that are given students are able to take the moral messages and knowledge in the film so that they can not only increase motivation but are able to change students' attitudes and mindset after watching the educational film.

Another study proposed by Hidayatuloh (2020) shows that there is a significant influence between the use of YouTube media and students' learning interest in fiqh subjects. The findings show that there is a significant effect between youtube users and students' learning interest in the seventh grade fiqh subjects at MTsN 4 Surabaya. The research has similarities with this research, namely the application of YouTube as a learning media can affect students' interest and motivation to learn.

Ifadah (2020) found that there was a significant influence between YouTube social media on the positive behavior of 5th grade students at MI Nurul Iman Kebonsari Madiun for the 2019/2020 school year. The magnitude of the effect is $42.3 \%$. Consistently following online learning is a positive behavior that must be developed by students. In the condition of the covid-19 pandemic, students are required to study from home and complete their duties as students.

Mujianto (2019) found that the use of YouTube as a learning media played a significant role in student learning motivation. YouTube is used to find information and entertainment. In addition, YouTube is also used to share videos so that students can be creative and make their own works. With such assignments, students will be more enthusiastic to participating in online learning because assignments and learning more variegated.

Based on the studies above, the used of YouTube media as a classical service media has an effect on students' learning motivation. By using YouTube media, students become interested and enthusiastic to following classical guidance services. When students watch a video given by the Guidance Counseling teacher, students can know new knowledge and learn from the video. So, it is hoped that after watching the video, students have a more positive attitude and mindset in participating in online learning consistently during the COVID-19 pandemic.

\section{Conclusion}

The results showed that the t-count value was 2.329, found t-table at a significance level of (0.05) of 2.021, which means t-table < t-count which means that youtube as a classical guidance media affects students' learning motivation during the COVID-19 pandemic. These results show that there is a significant difference in the increase in learning motivation in the experimental group who were given classical guidance services using youtube as a service medium and the control group who did not use youtube as a service medium. Classical guidance media in the form of youtube has several advantages over other classical guidance service

(The Influence of YouTube as a Classical Guidance Media on Student Learning Motivation during the Covid-19 Pandemic) 
media, including by using youtube as a learning media, students are more interested and enthusiastic in participating in classical guidance services. Apart from this, this study still has not yet perfect, including the research design used by the researcher where the researcher uses a true experimental design using a posttest only control group design. Researchers hope that in the future this research can be developed so that it can complement this research.

\section{Acknowledgement}

We express our deepest gratitude and appreciation for all the help, guidance, and contributions of all related parties who have worked hard for the development of this research. We express our gratitude to Mr. H. Achmad Sulaeman, Spd. as the principal of SMP Negeri 3 Kragilan who has allowed us to carry out research at SMP Negeri 3 Kragilan, to the homeroom teacher who is willing to cooperate with us, to Mrs. Ulan Sari, M.Pd who always guides us when we have difficulties and all other related parties who have provided support so that this research achieves the expected results.

\section{References}

Abidah, A., Hidaayatullah, H., Simamora, R., Fehabutar, D., \& Mutaqinati, L. (2020). The Impact of Covid19 to Indonesian Education and Its Relations to the Philosophy of "Merdeka Belajar". Studies of Science and Education, 1(1), 38-49.

Bao, W. (2020). COVID-19 and online teaching in higher education: A case study of Peking University. 113 115.

Basilaia, G., \& Kvavadze, D. (2020). ransition to Online Education in Schools during a SARS-CoV-2 Coronavirus (COVID-19) Pandemic in Georgia. Pedagogical Research, 5(4).

Cahyani, A., Listiana, I. D., \& Larasati, S. P. (2020). otivasi Belajar Siswa SMA pada Pembelajaran Daring di Masa Pandemi Covid-19. IQ (Ilmu Al-Qur'an): Jurnal Pendidikan Islam, 3(1).

Dantes, N. (2014). Desain Eksperimen dan Analisis Data. Singaraja: Undiksha Press.

Dwi, B., Amelia, A., Hasanah, U., Putra, A. M., \& Rahman, H. (2020). Analisis Keefektifan Pembelajaran Online di Masa Pandemi Covid-19. Jurnal Pendidikan Sekolah Dasar.

Farhatunnisya, A. (2020). Pemanfaatan Video Youtube Dalam Meningkatkan Motivasi Belajar Siswa Insan Litera. 3(2).

Hidayatulloh, M. S. (2020). Pengaruh Penggunaan Media Youtube Terhadap Minat Belajar Peserta Didik Pada Mata Pelajaran Fiqih (Studi Kasus Peserta Didik Kelas 7 MTsn 4 Surabaya). Surabaya: Universitas Islam Negeri Sunan Ampel Surabaya.

Hutabarat, H. D. (2020). Analisis Tingkat Kepuasan Mahasiswa Universitas Negeri Medan Terhadap Proses Pembelajaran Daring Ditinjau Dari Model Regresinya. Jurnal Fibonaci (Jurnal Pendidikan Matematika), 1(1).

Ifadah, M. (2020). Pengaruh Penggunaan Media Sosial Youtube terhadap Perilaku Positif Siswa Kelas 5 di MI Nurul Iman Kebonsari Madiun Tahun Ajaran 2019/2020. Fakultas Tarbiyah dan Ilmu Keguruan, Jurusan Pendidikan Guru Madrasah Ibtidaiyah. Ponorogo: Institut Agama Islam Negeri Ponorogo.

Isti'adah, F. N., Arumsari, C., Imaddudin, A., Sugara, G. S., Nugraha, A., \& Sulitiana, D. (2020). The Utilization of Technology as a Learning Media in Guidance and Counseling Service in Adaption of New Habits. Hasil Penenlitian dan Pengabdian pada Masyarakat V Tahun 2020. Purwokerto: LPPM - Universitas Muhammadiyah Purwokerto.

Kemendikbud. (2016). Panduan Operasional Penyelenggaraan Bimbingan dan Konseling Sekolah Menengah Atas (SMA). Jakarta: Kemendikbud.

Kemendikbud. (2016). Panduan Operasional Penyelenggaraan Bimbingan dan Konseling Sekolah Menengah Pertama (SMP). Jakarta: Kemendikbud.

Kummalasari, D. N. (2017). Kepuasan Peserta Didik Tehadap Pelayanan Proses. Jurnal Hanata Widya, 6, 1-6.

Mujianto, H. (2019). Pemanfaatan Youtube Sebagai Media Ajar Dalam Meningkatkan Minat dan Motivasi Belajar. Jurnal Komunikasi Hasil Pemikiran dan Penelitian, 5(1), 135-159.

Sadikin, A., \& Hamidah, A. (2020). Pembelajaran Daring di Tengah Wabah Covid-19. Biodik Jurnal Ilmiah Pendidikan Biologi, 6(2), 214-224. doi:https://doi.org/10.22437/bio.v6i2.9759 
Sardiman, A. M. (2020). Interaksi dan Motivasi Belajar Mengajar. Jakarta: PT. Raja Grafindo Persada. Sugiyono. (2017). Metode Penelitian Kombinasi (Mixed Methods). Bandung: Alfabeta.

Syachtiani, W. R., \& Trisnawati, N. (2021). Analisis Motivasi Belajar dan Hasil Belajar Siswa di Masa Pandemi COVID-19. Prima Magistra: Jurnal Ilmiah Kependidikan, 2(1).

Tohari, H., Mustaji, \& Bachri, B. S. (2019). Pengaruh Penggunaan Youtube Terhadap Motivasi Belajar dan Hasil Belajar Mahasiswa. Jurnal Teknologi Pendidikan, $7(1)$. doi:http://dx.doi.org/10.31800/jtp.kw.v7n1.p1--13

Article Information (Supplementary)

Conflict of Interest Disclosures:

The authors declare that they have no significant competing financial, professional or personal interests that might have influenced the performance or presentation of the work described in this manuscript.

Copyrights Holder: <jannah $><2021>$

First Publication Right: BISMA The Journal of Counseling

https://doi.org/10.xxxx/ $x \times x \times x$

Open Access Article | CC-BY Creative Commons Attribution 4.0 International License.

Word Count: 